\title{
French of the present and the past: the representation of the Parisian vernacular in Maurice Chevalier's songs*
}

\author{
Michaël Abecassis (Oxford)
}

\begin{abstract}
Today in France, there seems to be a resurgence of interest in 1930s French culture, with the release of Le Fabuleux destin d'Amélie Poulain (2001), set in Montmartre, and Patrick Bruel's re-edition of 1930s popular songs (2002). Songs of the 1930s and 1940s have hardly been exploited by linguists. I have compiled a corpus of Maurice Chevalier's songs whose lexical items I have analysed to assess how language has evolved. The stereotypical representation of the lower class which was a popular theme in musical-hall songs at that time enables the analysis of vernacular forms used at the beginning of the 20th century. I willendeavour in this analysis to establish the change in attitudes towardsthe standard and stigmatised language varieties in France by looking at lexicographers' labelling of non-standard items with stylistic indicators such as familier, populaire and argotique. I also intend to gauge through a survey conducted recently in France whether the once denigrated français populaire found in Chevalier's songs is obsolete or whether it is still used in the 21 st century.
\end{abstract}

Keywords: songs, French, français populaire, Maurice Chevalier, non-standard, lexis

\section{$1 \quad$ Introduction}

The influence of the mass media on language has led to a large number of studies (Chambers 1998, Bernet 2000, Colin 2000), but hardly any linguist has worked on a corpus of songs with the exception of a few references to popular French songs (Bernet 1995, Carton 1995). Whether the media plays a major influence on language is highly controvertial, leading to generalisations such as that the media invents words and disseminate them, sometimes even arguing that this entails sound and grammatical changes. The sociologist S. Lieberson (2000), looking at the correlation between names familiar from the media and the way people name their children, found that people tend to overestimate the influence of the media. Instead of popularising names, he showed that the media are not responsible for an active change and only reflected language changes that were already entrenched. Labov (1984) showed that in the inner-city of Philadelphia, daily passive exposure to standard English language on television and education has little effect on the dialect of young African American residents.

\footnotetext{
* I am very grateful to Professor Lodge for his numerous comments and Dr W. J. Anderson for her help in proofreading.
} 
Milroy /Milroy argue on the contrary that the media, such as television do have an influence in spreading idioms and popularising innovations, but viewers would not necessarily adopt them in the long run (Bauer 1994: 7-8). The analysis here will investigate what Chevalier's songs, although highly stereotypical and artificial, can tell us about the Parisian vernacular, and whether they had some kind of influence, keeping the vocabulary popularised at the time by Chevalier alive today.

For this study, I compiled a corpus of Maurice Chevalier's best known songs, recorded over almost three decades between the 1920s and 1950s, in order to analyse his use of nonstandard vocabulary. Maurice Chevalier is the archetype of popular Parisian singers and his songs have become world-wide classics. In the first part of this analysis, after giving a brief outline of the phonetic features of Chevalier's songs, we will concentrate on the proportion of non-standard items in his songs and follow the evolution of his vocabulary diachronically. The main purpose of this research is to gauge the evolution of Chevalier's lexicon by taking into account the attitudes of lexicographers of Le Petit Larousse (2004) towards non-standard items and the perception of native French speakers towards their usage.

Maurice Chevalier was born in 1888 in Ménilmontant, a working-class district of Paris. His father, a house painter, was Parisian by adoption and his mother was of Belgian origin. After holding various jobs in Paris as a child, such as a circus acrobat and an impersonator of the French Comique-troupier Dranem, he became a "comic" singer in Paris café concerts and later in the Folies Bergères. An admirer of Fréhel and Mistinguett, he moved from a popular repertoire to that of a dandy, clad in a suit and wearing his famous boater. During the années folles, the French singer started a career as a Hollywood actor where he became an ambassador for French culture.

The popular songs of the music-hall made their way onto French radio as early as the 1920 s with Aristide Bruant, Monthéus and Fragson. While the female singers (Damia, Fréhel and Marie Dubas) characteristically indulged in melodramatic songs, singing of the misfortunes of prostitutes, drug-addicts and abandoned lovers, the male singers (Mayol, Georgius, Milton) sang farcical songs, with an often purposefully idiotic vocabulary. Since they were masters of parody, manipulators of words, and virtuosos of phraseology, their songs were often mere exercises in elocution which consisted of pronouncing as many words as possible before taking breath. Ostentatiously rejecting grammatical rules, Comique-troupiers, like Chevalier deliberately perpetrated in their songs grammatical and pronunciation errors, the French pronunciation of English words ("Liverpoole", "Novyorke") for example, and excelled in the art of innuendo. Recordings of their songs remain today as some of the oldest archives of Parisian vernacular:

C'est peut-être la chanson et les chansons, qui à travers les formes traditionnelles et les formes plus modernes nous apportent des images les plus fidèles du Langage Populaire. Avec le développement du Caf' Conc (Gaité-Rochechouard, Gaité-Montparnasse) et des cabarets (Lapin à Gill, Chat noir...) se répandent dans une forme de spectacle nouvelle les chansons de Bruant, de Mayol, d'Yvette Guilbert (François 1999: 309). 
Apart from the 'cris de la rue' of street vendors and conversations recorded on sapphire disc available at the national sound archive of Paris (Antoine/Martin 1985: 298, note 8), recordings which provide information about this period are extremely rare. Therefore, 1930s songs, even if they offer us a pastiche of Parisian speech, are valuable evidence of vernacular speech.

There are two types of songs by Chevalier: some are written in highly literary style with hardly any colloquialisms, while others use colloquial items to create a humorous effect. As the heir of Comique-troupiers such as Ouvrard and Dranem, Chevalier indulged in the 1930s in rather coarse and light-hearted songs ("Le chapeau de zozo", "Prosper" "Valentine") which made him famous as "le p'tit gars de Ménilmuche", then he gradually shifted to a more serious repertoire ("Ça sent si bon la France", "Heure exquise", "Notre espoir") asserting the values of "famille, travail, patrie". Les années folles were a time of extravagance and the unbridled pleasure of intellectual emancipation and linguistic freedom. We find a type of verbal emancipation in les années folles, but "l'état de 'guerre froide' qui instaure sournoisement de nouvelles restrictions, voire de vraies censures par rapport à l'expression verbale de 19441955" (Colin 2000: 151) was very quick to establish itself. Like many Parisians at the end of the 19th century (Petitpas 2003), Chevalier favours the abbreviated and resuffixed forms "Pantruche" (1835) for Paris, "Boul' Mich'" (1878) for Boulevard St Michel, "Ménilmuche" (1881) for Ménilmontant and "Lap" for la Rue de la Paix.

\section{The evidential value of the data}

It goes without saying that songs are not a direct reflection of spontaneous language and are conditioned to a great extent by conventional expectations and stereotyping ${ }^{1}$. Here we make no strong claims about the representativity of this data, since they are a product of a stabilised tradition and a collective creation partly of the lyric writer and partly of the singer. However, though this recorded material is not spontaneous speech, it remains a document of the 1930s1950s period and is anchored in the linguistic realities of the day. Chevalier's songs give us a subjective view of the objective linguistic reality of that period.

The linguistic analysis of this type of song poses many methodological problems and one has to make some ad hoc choices when compiling a corpus. It is often difficult for instance to establish which singer was the first interpreter of a song. Chevalier commonly sang Trénet's "Y'a d'la joie" and although the lyrics are exactly the same in both versions, Chevalier's interpretation (his tone of voice, the stress and intonation) is very different from Trénet's. We have included a version of Chevalier's "Y'a d'la joie" in the corpus, although the lyrics were not originally written for him. Besides, it can be argued that each interpretation of a song

\footnotetext{
${ }^{1}$ Stereotypes are highly stigmatised variables recognised by a particular group as mistakes or affected manners of speech (adapted from Baylon 1991: 91-2 and Wardhaugh, 1986: 142). Note that "stereotypes" could be understood in the Labovian sense, as defined above, or in a broader sense as "value judgments about what [the lay-person] think[s] is and is not correct" (Lodge et al. 1997: 3) about a language as well as 'evaluations of speakers' (Wardhaugh 1986: 113).
} 
offers a different version of the lyrics. In the version we used of "Valentine", the famous line "elle avait de jolis petits tétons..." becomes "elle avait un si joli piton...". This corpus of texts can consequently be said to be, like the performance of a play, a one-off, stylised representation of the Parisian vernacular at a particular moment in time.

\section{The corpus}

Our corpus of Chevalier's songs comprises the following 41 songs presented here in alphabetical rather than chronological order, as some dates are unknown. The dates refer to when the songs were recorded, rather than to when they were composed. The total number of words for each song is indicated in parentheses.

Song 1: Ah! Si vous connaissiez pas poule 1938 (297 words)

Song 2: App'lez ça comme vous voulez 1939 (390 words)

Song 3: Arthur, fox à poils durs 1939 (353 words)

Song 4: Ça fait d'excellent français 1939 (328 words)

Song 5: Ça sent si bon la France 1941 (302 words)

Song 6: Ça s'est passé un dimanche 1939 (345 words)

Song 7: Dans la vie faut pas s'en faire 1922 (163 words)

Song 8: Dites-moi ma mère 1941 (391 words)

Song 9: Donnez-moi la main mamzelle 1935 (301 words)

Song 10: Fleur de Paris 1944 (175 words)

Song 11: Heure exquise? (135 words)

Song 12: J'ai peur de coucher seul 1930 (358 words)

Song 13: La chanson du maçon 1941 (296 words)

Song 14: La choupeta? (230 words)

Song 15: L'amour est passé près de chez vous 1937 (257 words)

Song 16: La Polka des barbus 1942 (250 words)

Song 17: Le chapeau de zozo 1936 (356 words)

Song 18: Ma pomme 1936 (209 words)

Song 19: Marche de Ménilmontant 1942 (186 words)

Song 20: Ma régulière 1927 (218 words)

Song 21: Marguerite? (283 words)

Song 22: Mimi 1930 (196 words)

Song 23: Mimile 1936 (457 words)

Song 24: Mon cocktail d'amour 1932 (147 words)

Song 25: Mon vieux Paris 1936 (156 words)

Song 26: Notre espoir 1941 (204 words)

Song 27: Oh Maurice 1920 (297 words)

Song 28: On est comme on est 1938 (385 words)

Song 29: Paris je t'aime d'amour 1932 (136 words)

Song 30: Paris sera toujours Paris 1939 (281 words)

Song 31: Pour les amants c'est tous les jours dimanche 1947 (177 words)

Song 32: Prosper (Yop la boum) 1935 (296 words) 
Song 33: Quai de Bercy 1946 (370 words)

Song 34: Quand on revient? (219 words)

Song 35: Quand un vicomte 1935 (172 words)

Song 36: Sur un air américain 1920 (321 words)

Song 37: Une brune, une blonde ? (303 words)

Song 38: Un p'tit air 1938 (248 words)

Song 39: Valentine 1928 (175 words)

Song 40: Y'a d'la joie 1937 (344 words)

Song 41: Y'a du bonheur pour tout le monde 1936 (185 words)

\section{$4 \quad$ Phonetic features}

In this section, a brief picture will be given of firstly the suprasegmental features recurrent in the corpus and secondly of the segmental features. Maurice Chevalier's songs show a reinforcement and a lengthening of the penultimate syllable. Carton notices that in music-hall songs by Mistinguett or Maurice Chevalier "l'avant dernière syllabe de groupe est longue, intense et monte souvent 'en creux' " (Antoine \& Martin 1995: 55). "Monter en creux" means a melodic concave ascent and is the opposite of "en bosse". In French, rising intonations on the accentuated syllable are generally concave. Concavity gives an impression of dawdling (Carton, personal communication, 2000). The example of Chevalier's "ma pômme/ c'est moi" is, as Carton asserts, stereotypical Parisian vernacular with the stress on the penultimate long open vowel [ma `pom]. The /mwa/. is lengthened to make the voice tremor (ibid.).

The trilled uvular $/ \mathrm{r} /$ is another salient feature of Chevalier's songs (Tranel 1987: 141). As Carton has indicated, Maurice Chevalier's / $\mathrm{r}$ / was not a lower-class feature of Ménilmontant, but belonged to the singing tradition and can still be found today in opera singing. Chevalier imitated Georgius "qui avait des /r/ systématiquement 'd'avant' " (Carton 2003, personal communication). The following table presents the various pronunciations of $/ \mathrm{r} /$ in a sample of Maurice Chevalier's songs recorded in 1955. 


\begin{tabular}{|c|c|}
\hline Le chapeau de Zozo & $\begin{array}{l}\text { apico-dental : flap (léger battement), surtout à l'initiale } \\
\text { ('rigolo') après consonne ('cri'), même devant consonne } \\
\text { (n'importe qui), rarement en finale }\end{array}$ \\
\hline Folies Bergères & flap léger \\
\hline Ma pomme & $\begin{array}{l}\text { parler faubourien exagéré: plusieurs R d'arrière sourds } \\
\text { (voix d'ivrogne). }\end{array}$ \\
\hline La Chanson du maçon & flap apical et uvulaire doux mélangés \\
\hline $\begin{array}{l}\text { Marche de } \\
\text { Ménilmontant }\end{array}$ & $\begin{array}{l}\text { pas pharyngal mais dorso-uvulaire sonore et léger, avec } \\
\text { traces de flaps: remontant, redescendant: (expressivité?) }\end{array}$ \\
\hline Mimile & flap léger \\
\hline Prosper & $\begin{array}{c}\text { dorso-uvulaire doux, pharyngalisé dans l'emphase } \\
\text { ('carrément') }\end{array}$ \\
\hline Quand un vicomte & $\begin{array}{c}\text { surtout flap ( }=\text { un seul battement) } \\
\text { initial }\end{array}$ \\
\hline
\end{tabular}

Table 1: Representation of the phoneme /r/ in a 1955 recording

(Carton 2003, personal communication)

In this corpus of Chevalier's songs, other salient features are the elision of the schwa in "je" as well as the use of the reduced form "y'a" for "il y a", but we will focus here on non-standard lexical items. In numerous films from the 1930s to 1960s (Fric-frac 1939, Touchez pas au grisbi 1954, Du Rififi chez les hommes 1955, Les Tontons flingueurs 1963) which play upon the attractive and mysterious language of criminals in the collective imagination; it is the lexical characteristics which most clearly give speech a slang 'colour' ${ }^{2}$. The same is true of the popular songs of the period.

\section{$5 \quad$ Use of non-standard items in Maurice Chevalier's French songs}

By "non-standard", we refer to lexical items which have been labelled fam., pop., arg. etc. by Le Petit Larousse (2004) or which have been excluded from it. The latter words would appear in the following statistics as absent.

In these statistics, 'items' include phrases as well as as individual words. The use of colloquial proper nouns ("Momo", "Mimi" and "Mimile") is very frequent in Chevalier's songs and such examples have been included. We will make no distinction between words and idioms. An idiom like "s'en mettre plein les trous de nez" will count as one item. Further, we have left out onomatopoeic expressions such as "tra la la la", "dzim pa poum pa la" or "ton ton tontaine" which are one-off onomatopoeic creations.

\footnotetext{
2 In Fric-Frac, the representation which scriptwriters and actors give of the Parisian vernacular is mostly phonetic and lexical. In films from the 1950s, the emphasis is on lexical features. In Du Rififi chez les hommes, for instance, the speech of gangsters is full with non-standard items. Les Tontons flingueurs is not so much peppered with argot words, as with one-off lexical creations ("Ton Antoine commence à me les briser menu"; "Moi quand on m'en fait trop, j'correctionne plus, je dynamite, je dépense, je ventile").
} 
We use Le Petit Larousse's latest edition (2004) as a yardstick, to evaluate the percentage of non-standard items in the corpus. The purpose of this analysis is to investigate lexicographers' perception of these items and their evolution from 1920 to today.

We count tokens rather than types, taking into account several occurrences of a lexical item. Lexical items which appear in a chorus appear in the quantification as many times as they occur, as the lyrics often vary from one chorus to the other and new vocabulary is introduced.

The total of non-standard words in the Chevalier corpus, when one averages the percentage for each individual song, amounts to only $3 \%$. Lexical variables are highly self-conscious and highly salient. Few are needed to create the 'slang effect'. The percentages of non-standard words in each individual song shown below (Figure 1) indicate that the proportion rarely exceeds 20\%. The song "Appelez ça comme vous voulez", where Chevalier accumulates instances of colloquial words and expressions, obtains the highest score with $21 \%$, which is a large proportion of the $3 \%$ overall figure quoted earlier. Taking into account that there is a predominant percentage of function words (prepositions, conjunctions, articles and interjections for instance), this percentage of non-standard lexical items represents quite a high ratio.

In the following statistics, we have grouped percentages for individual songs in a chronological order and intend to show the progression of slang as Chevalier moves from prewar to Occupation and to Collaboration. We have classified our sample of Chevalier's songs into three chronological periods: 1920-9, 1930-9, 1940-9. Some of these songs Chevalier sang throughout his career, but by looking at different time periods, we hope to bring out a trend in Chevalier's career.

\begin{tabular}{|c|c|c|}
\hline $1920-9$ & $1930-9$ & $1940-9$ \\
\hline $5 \%$ & $4 \%$ & $2 \%$ \\
\hline
\end{tabular}

Table 2: Use of non-standard items in Chevalier's songs from the 1920s to 1940s 


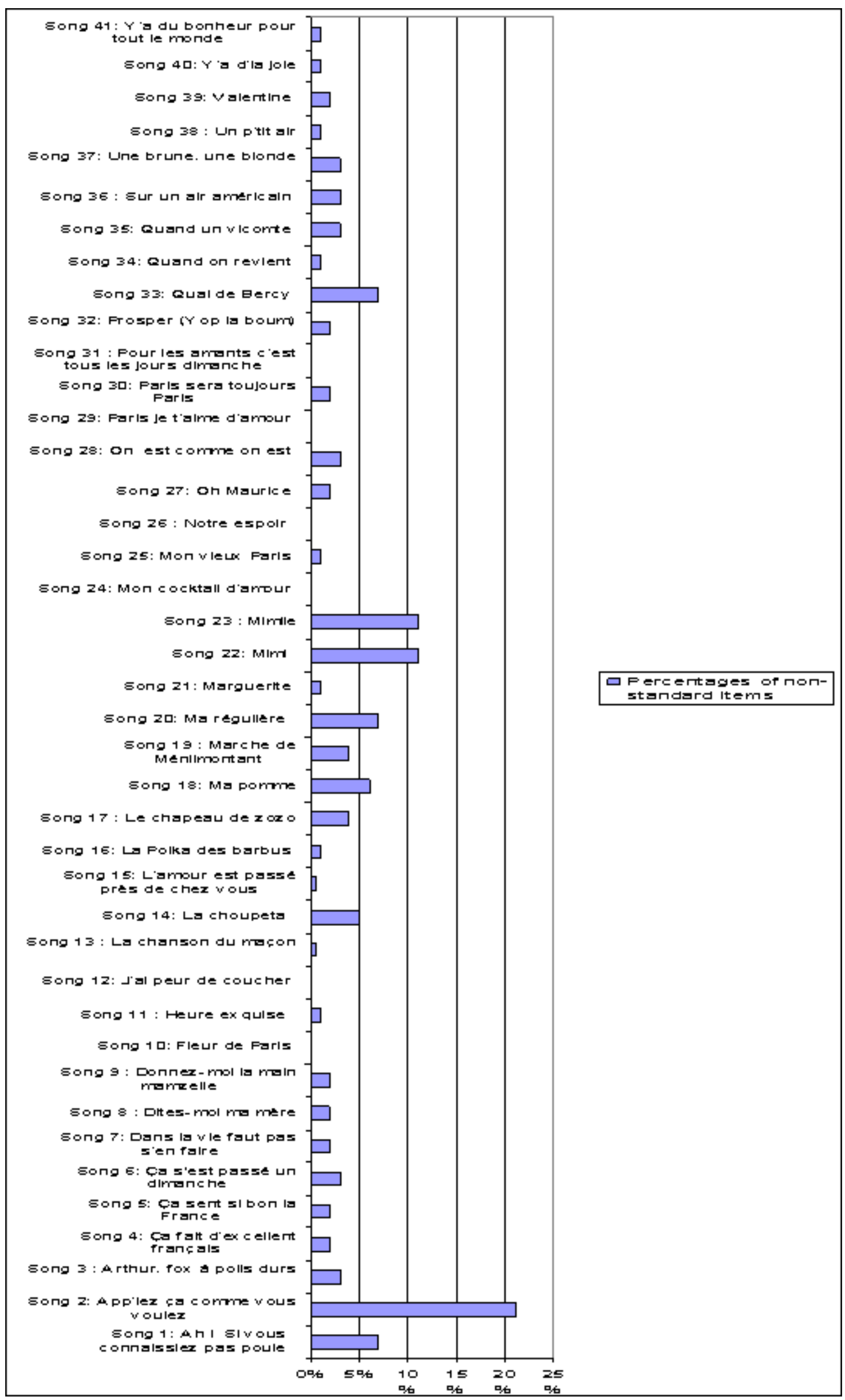

Figure 1: Percentages of non-standard items in Chevalier's songs 
The results show a slight decline in the use of non-standard items in Chevalier's songs from the 1920 s to the 1940s, as he moves from a popular register to a more literary and poetic repertoire.

\section{$6 \quad$ Variety of lexical items}

In this section, we examine at the Chevalier song "App'lez ça comme vous voulez" which has the highest number of non-standard words. We have divided the song into its different word-classes (verbs, nouns, adjectives and auxiliaries), grouping together articles, particles, prepositions, conjunctions, clitics and interjections as 'tool-words'. In this quantification, we will consider lexical items as tokens rather than types. If the adjective "petit" occurs twice, this will count as two occurrences.

By means of comparison, we present here results from Müller's 1985 study and show the categories of vocabulary items, with their respective proportions, that can be found in three different corpora:

a) the corpus of a dictionary (Le Petit Larousse), presumably 'potential' of the language

b) the written corpus of articles drawn from one issue of Le Monde

c) the corpus of spoken French from Le Vocabulaire du français fondamental (1er degré)

\begin{tabular}{|c|c|c|c|}
\hline Categories & $\begin{array}{c}\text { Le Petit Larousse } \\
\text { date unspecified } \\
(44,500 \text { lexical } \\
\text { items in total })\end{array}$ & $\begin{array}{c}\text { Le Monde } \\
\text { Date unspecified } \\
(4,800 \text { lexical items in total) }\end{array}$ & $\begin{array}{c}\text { Le français fondamental } \\
1964 \\
(1,475 \text { lexical items in total) }\end{array}$ \\
\hline nouns & $62.5 \%$ & $55 \%$ & $46.9 \%$ \\
\hline adjectives & $19 \%$ & $16 \%$ & $6.6 \%$ \\
\hline verbs & $15 \%$ & $22 \%$ & $22.9 \%$ \\
\hline adverbs & $3 \%$ & $4 \%$ & $5.6 \%$ \\
\hline $\begin{array}{c}\text { grammatical words } \\
\text { (articles, pronouns, } \\
\text { prepositions, } \\
\text { conjunctions }\end{array}$ & $0.5 \%$ & $3 \%$ & $\begin{array}{c}17.1 \% \\
\text { (with } 0.9 \% \text { of interjections etc.) }\end{array}$ \\
\hline
\end{tabular}

Table 3: Categories of vocabulary items (adapted from Müller 1985: 127)

According to Müller's findings, nouns and verbs are the most frequent word-classes in the three corpora investigated. The percentage of adjectives is high, but only relatively high in $L e$ français fondamental. The number of tool-words only accounts for a small percentage except in statistics for the oral corpus of Le français fondamental where they amount to $17.1 \%$. 


\begin{tabular}{|c|c|c|c|c|c|}
\hline & verbs & nouns & adjectives & auxiliaries & Tool-words \\
\hline Percentage of lexical items & $11 \%$ & $13 \%$ & $2 \%$ & $1 \%$ & $73 \%$ \\
\hline
\end{tabular}

Table 4: Proportion of constituents in song 2

Chevalier's songs are, unlike the literary style of Le Monde, quite poor lexically. Some features of spoken French are present such as short and loose constructions and phrasal repetitions. Adjectives are quite basic ("beau", "joli", "rigolo") and their proportion relatively small, and the high frequency of key-words, the majority of which are articles, interjections and onomatopoeic items, also contribute to the spontaneity and musicality of Chevalier's songs. Non-standard nouns build up, like an exercise in style or an elocution lesson, as in Vincent Scotto's song, sung by Ouvrard:

"J'ai la rate

Qui s'dilate

J'ai le foie

Qu'est pas droit

J'ai le ventre

Qui se rentre

J'ai l'pylore

Qui s'colore

J'ai l'gésier anémié" (1932 "Je ne suis pas bien portant").

In this way, Ouvrard, through a succession of nouns and verbs, builds up the anatomical and medical references. We can note that the words generally used in Chevalier's choruses are usually of three syllables or less:

"Avez-vous vu le chapeau de zozo,

C'est un chapeau, un papeau rigolo" Le Chapeau de zozo

Alliterations using /v/, /p/ and /o/ in Le Chapeau de zozo serve to add to the onomatopoeic and speech-like character of the chorus. The nouns give a basic picture and provide a sketch of the characters involved. In $Y^{\prime} a$ d'la joie, the lexemes "joie", "toit" and "hirondelles", "soleil", "ruelles", "demoiselles" provide the framework and bring out the spirit of the song whose main character is the singing "moi", "je", or "Maurice". The verbs make the nouns dynamic ("bat", "chavire" and "chancelle").

\section{Vitality of non-standard items found in Chevalier's songs in today's French}

In this section, we investigate attitudes towards the non-standard items used by Maurice Chevalier implicit in Le Petit Larousse's (2004) treatment of these words (see glossary) and in judgments expressed by a sample of Parisian speakers in 2004. In the study I conducted on non-standard vocabulary in the 1930s film corpus (Abecassis 2000), I pointed out that many social markers have gradually become stylistic markers and have merged into French speakers' linguistic passive repertoires (Posner 1997: 74): even though socio-stylistic variation operates concurrently, the lexis which constitutes the "doublet parasite du standard" (Gadet 
2003: 110) has lost part of its sociological dimension. Our findings indicated that nonstandard words found in 1930s dialogues were still commonly used, regardless of social status. From these statistics, we evaluate the extent to which items in the Chevalier corpus have disappeared. There seems to be in the language of French youngsters a resurgence of colloquial words through the media and most particularly in songs:

Des émissions grand public à la radio et à la télévision contribuent à la diffusion de tout un vocabulaire, d'intonations particulières, de l'accent des cités (Goudaillier 2000)

If we agree that television and the media in general have contributed to the increase in formulae and linguistic traits (Bernet 2000: 191), it would not be surprising if songs have been the source of lexical innovations or have spread out-dated popular formulae. It is noticeable that archaic lexical items originating from traditional argot often emerge among the young (Gadet and Conein 1998: 115-116). The singer Renaud, in his 1975 album, reintroduces the terms "Paname" (argot for Paris), "aminche" and "gavroche". Words like "maille", "flouze" and "poteau" are also frequently found in lyrics of rap songs popular in the 21st century. The surveys conducted by Walter between 1987 and 1989 (Walter 1991) show that more than half of the argot words originate from the specialised texts investigated and date back to before 1945 (Colin 2000: 168). As for the non-standard lexical items in the Chevalier corpus, we do not see them as items which have died out and which youth has recently resuscitated, but as items which have always been in the passive linguistic repertoire, absent from public notice and then brought back into fashion by an influential song or film. The verlan 'ripoux', for instance, re-emerged in the public arena when popularised by Claude Zidi's film in the 1980 s and its numerous sequels.

\subsection{Speaker variables}

Informants were asked firstly whether they were familiar with a list of non-standard words extracted from the Chevalier corpus and secondly whether they would use these words themselves. The left-hand column in table 3 shows the percentage of items unknown to the informants, the second presents the percentage actually used and the third the percentage of lexemes the informants are familiar with but do not think that they use. Most of the informants were contacted by e-mail and were unknown to the interviewer, which restricted the sample to those who were computer literate. The informants fall into five broad age categories: a) 15-20, b) 21-30, c) 31-40, d) 41-50 and e) 50+. Considering a sample of twenty educated Parisian speakers in each age bracket is a satisfactory number and should be expected to produce representative results. Moreover, by focusing on informants selected according to the sociolinguistic axes along which language variation operates (age, sex and class), we have tried to establish whether these items have become less stigmatised and become part of their everyday natural speech. Armstrong and Hogg (2000) have conducted a similar study on the use of non-standard lexis which they corroborated by basic statistic tests like ANOVA to see whether the groups are in fact behaving like groups.

Table 5 shows differentiation between the male and female speakers' use of these nonstandard items. Only an average 53\% of traditional slang found in the Chevalier corpus is 
recognised by the informants to be part of their general vocabulary. The remaining $47 \%$ is either unknown or unused by them. Table 6 and Figure 2 show considerable variation in the perceived use of the vocabulary according to age and gender parameters.

\begin{tabular}{|c|c|c|c|}
\hline & $\begin{array}{c}\text { Percentage of } \\
\text { lexical items } \\
\text { unknown }\end{array}$ & $\begin{array}{c}\text { Percentage of } \\
\text { lexical items used }\end{array}$ & $\begin{array}{c}\text { Percentage of lexical } \\
\text { items known but not } \\
\text { used }\end{array}$ \\
\hline Female speakers (15-19) & $41.5 \%$ & $41 \%$ & $17.5 \%$ \\
\hline Male speakers (15-19) & $42 \%$ & $52 \%$ & $15 \%$ \\
\hline Female speakers (20-29) & $36 \%$ & $49 \%$ & $16 \%$ \\
\hline Male speakers (20-29) & $28 \%$ & $56 \%$ & $3 \%$ \\
\hline Female speakers (30-39) & $29 \%$ & $59 \%$ & $42 \%$ \\
\hline Male speakers (30-39) & $5 \%$ & $60 \%$ & $20 \%$ \\
\hline Female speakers (40-49) & $21 \%$ & $37 \%$ & $14.5 \%$ \\
\hline Male speakers (40-49) & $39 \%$ & $41 \%$ & $1 \%$ \\
\hline Female speakers (50+) & $32.5 \%$ & $53 \%$ & $18 \%$ \\
\hline Male speakers (50+) & $15 \%$ & $84 \%$ & $53 \%$ \\
\hline AVERAGE & $29 \%$ & $53 \%$ & $12 \%$ \\
\hline
\end{tabular}

Table 5: Percentage of lexical items per gender

\begin{tabular}{|c|c|c|c|c|c|}
\hline & $15-19$ & $20-29$ & $30-39$ & $40-49$ & $50+$ \\
\hline Female speakers & $41 \%$ & $49 \%$ & $59 \%$ & $37 \%$ & $53 \%$ \\
\hline Male speakers & $52 \%$ & $56 \%$ & $60 \%$ & $41 \%$ & $84 \%$ \\
\hline
\end{tabular}

Table 6: Percentage of use of non-standard items

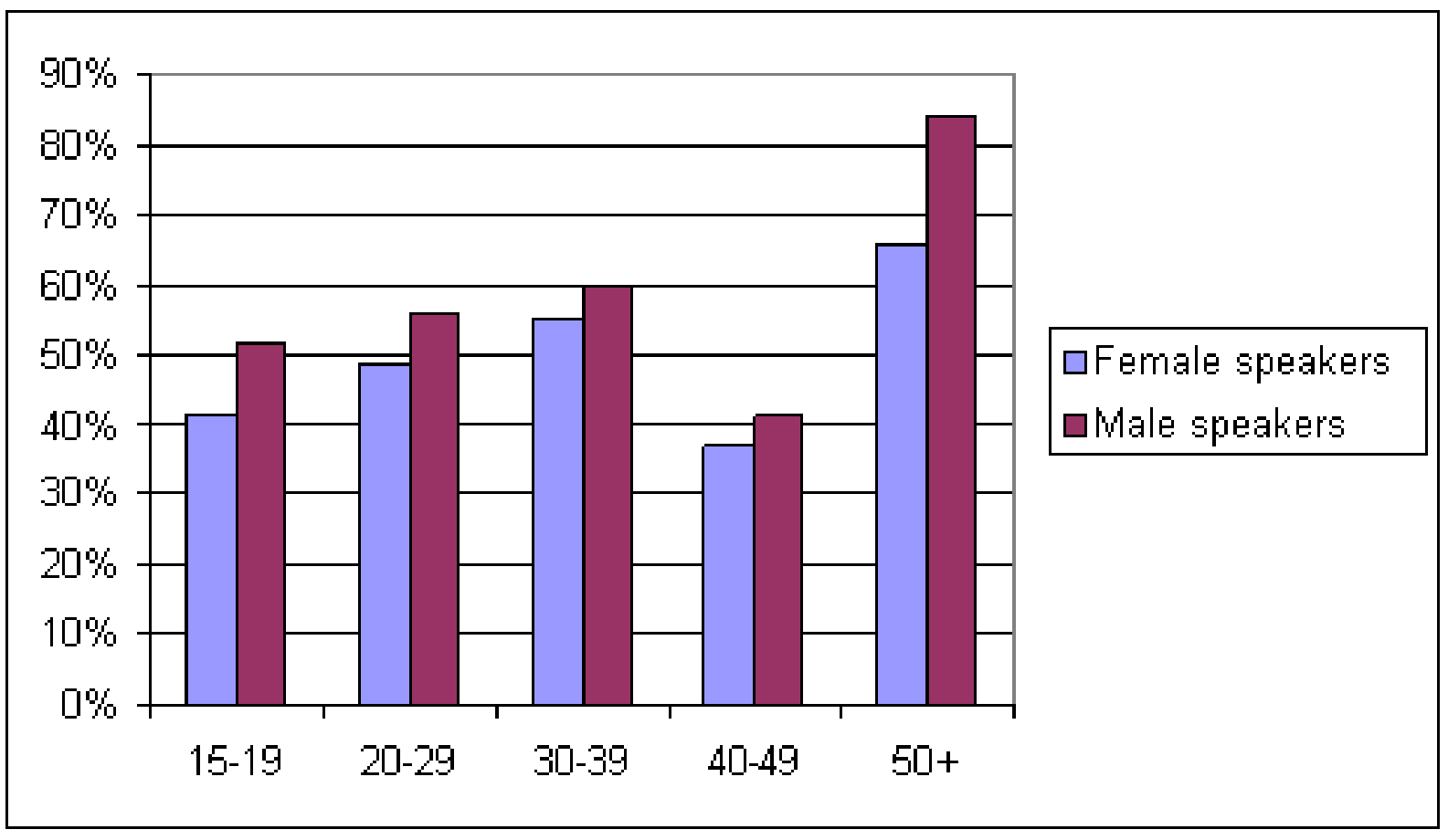

Figure 2: Percentage of use of non-standard items 
When we compare the type of slang used by Maurice Chevalier with that found in 1930s gangster films (Abecassis 2000), fewer lexical items in Chevalier's songs have survived in common usage. Column 2 of Table 5 shows that percentages of unknown items vary between $5 \%$ to $42 \%$.

Column 3 shows clear sex differences in all age groups where the percentage of use of nonstandard forms by male speakers is relatively higher than that of the female informants. Female informants still achieve quite high scores. These results comply with the "sociolinguistic gender pattern" illustrated by Milroy (1987) and Armstrong/Hogg (2000). The results in the 15-19 age-group indicate quite a high percentage of use of non-standard items among the youth. The questionnaire results also testify that the percentage of use of non-standard lexis increases with the age of the informants reaching its peak among the 50+ cohort. However, over the whole range, the 40-49 cohort was born between the mid-50s and $60 \mathrm{~s}$, at a time when popular French music experienced some major changes and was largely influenced by America.

Column 4 shows that on the whole, the female informants present through these results a more conservative image, as the figures demonstrate that they know a higher number of the investigated items but would not use them. This indicates a high degree of awareness on the stylistic value attached to this sample of Chevalier's lexis.

The fact that older informants rather than the younger generations were exposed to some of the cryptic slang of Chevalier ("calter", "un bibi", "un zozo", "un piton") is rather unsurprising. Chevalier's heyday, both as singer and actor, was between the 1930s and the 1960s. In 1958, he made the film Gigi and that year received an Oscar. In the 1970s, in spite of singing the title song of Walt Disney's Aristocats, he became less well-known among adolescents and fell out of fashion in favour of other chansonniers (Brel, Brassens, and Bécaud among others). Another related factor should be taken into account: the disappearance of some lexical items popularised by Chevalier. Young people's culture, concerns and topics of conversation have shifted, and traditional slang associated with drinking, love and the milieu of gangsters are no longer representative of the social persona of the youngsters of the time. The class structures of the 1930s have been superseded by new ones. Nonetheless, the percentage of use by teenagers is still relatively high, showing a resurgence of some of these words. Quite interestingly, the percentage of lexical items they claim to know but do not use is extremely high. Is it mere boastfulness from the younger informants to argue so or is this vocabulary really spreading in the language of young people? The sample presented is not sufficiently representative to confirm the exact tendencies of youth behaviour in this regard. From 50+ speakers to 15-19 informants there is clearly, as shown in table 6, a progressive decline in the use of slang.

The high frequency of non-standard items in female speech in the data can be interpreted in various ways. Chevalier's songs have always been particularly popular among women. His accent and charisma made him the epitome of the French lover in France as in America. It could also be that the males questioned use a different colloquial vocabulary, drawing on other sources such as verlan, thereby appearing to diverge strongly from Chevalier's findings. 
This would mean that, contrary to the results, the languages of females may be a lot more conservative than that of their male counterparts. However, as Holmes (1997) remarks "no satisfactory explanation has emerged of why women should orient more readily than men to a prestige norm" (Quoted in Milroy and Gordon, p. 101) and we suggest that we might be dealing here with a process of "social re-valuation" (Ibid.: 103). Female speakers favour stigmatised varieties and subvert traditional female roles by means of a familiar usage, enabling a more cohesive mentality, marked by solidarity and group identity, in a society which is increasingly liberal. The real innovation in youth language is the emancipation of female language both among educated speakers, such as those in our survey, and in less privileged groups. Popular features and cheeky humour have often been stereotypically associated with young men who frequent public places like bistros (Gadet 2003: 206), whereas women are considered more likely to remain within the home, and, under parental authority, conform linguistically to prestige varieties. In the $21^{\text {st }}$ century, the use of a nonstandard lexis is no longer prompted by the desire to appear "male", as connections between men and women become more and more subtle, owing to equality between sexes and shared vocabulary.

\subsection{Stylistic variables}

In a second stage of this survey, we asked our informants to rate the non-standard items of the Chevalier corpus to establish whether their views differ from those of lexicographers. The following table shows the proportions of items in the song corpus rated as fam., arg. and abs. by our reference dictionary (Le Petit Larousse 2004).

\begin{tabular}{|c|c|c|c|c|c|c|c|c|}
\hline anglicism & $v x$ & vieilli & enf. & fam. & très fam. & arg. & vulg. & abs. \\
\hline $1 \%$ & $1.5 \%$ & $8 \%$ & $1.25 \%$ & $53 \%$ & $1 \%$ & $6 \%$ & $1.25 \%$ & $27 \%$ \\
\hline
\end{tabular}

Table 7: Proportion of non-standard items according to style-labels of Le Petit Larousse (2004)

The majority of the items investigated are labelled by Le Petit Larousse as fam. There is a small number of argot words, but none is rated as populaire. This suggests that formerly pop. words have gradually become fam. in the eyes of lexicographers. $27 \%$ of these items are exluded from the dictionary, which either implies that they have not survived in modern French or that they are still heavily stigmatised.

To obtain the following statistics, we asked our informants to rate each lexical item using the labels fam., standard or archaic. We are aware that this is a simplification of the stylistic continuum used by lexicographers and other labels could be attributed to the items of our corpus such as pop., arg. or both fam. and archaic. However, for the purpose of this quantification, this enables us to gauge whether the people questioned thought that these items have merged into the average French person's linguistic repertoire and have become standard or whether they are considered to be obsolete. 


\begin{tabular}{|l|c|c|c|c|}
\hline & standard & fam. & arch. & Don't know \\
\hline Informants perception (2004) & $24 \%$ & $47 \%$ & $20 \%$ & $9 \%$ \\
\hline
\end{tabular}

Table 8: Proportion of non-standard items according to people's perceptions today (2004)

As one can see, the informants rate a large percentage (47\%) of these items as fam., which is very close to the attitude of lexicographers. However, their view is less stigmatising as they consider that $24 \%$ of these items have become standard and $20 \%$ are now obsolete.

Linguists have attempted to identify the reasons why argot words should remain current in French, and the growing number of dictionaries of argot (Bernet 2000: 174) shows the French interest in these curiosities which have almost reached the status of national cultural heritage. We only have to think of clichés and other quirky lexical features which have been collected together. There is indeed an oral tradition which passes from generation to generation and which sometimes goes underground for a generation, to become current again much later, as in Renaud's songs. Slang is an identity marker and the more it is generalized, the less useful it is, but if in today's French it has a tendency to spread through all levels of society, this is as Colin (2000: 160) has shown, because of a number of factors. Our language is becoming increasingly technical and the intrusion of information technology and types of jargons associated with technical specialized professions has a tendency to crop up in everyday language (e.g. "CD ROM", "digitaliser", "startup"). There is not simply the ludic pleasure of playing with words demonstrated by "bons mots", irony and self-mockery, puns and other rhetorical devices used by many French humorists (Pierre Desproges, Karl Zéro, Vincent Roca, Guy Carlier), heirs to cabaret singers, who find the mark of a group identity in the use of argot, and in this way confine themselves to the outskirts of society, because it is primarily the desire to upset, provoke or shock which keeps argot active. Roca's witticism for his satirical TV programme 'Sur le fil dérisoire' (2004) is only one example of this continual seach for a play on words combining spirituality and double-entendre. Some radio stations (NRJ, Fun Radio) and the cable television channel Canal + , in seeking to convey a young, lively image, use a subversive vocabulary. This desire to veil the message is a form of rejection of all forms of authority, both the symbolic rejection of the constraints of parental authority and good linguistic manners imposed by the norm, and the refusal to conform to rules. The overuse of the adjective "cool" by the youth today pinpoints a state of mind and the need to project an image of protest against the propriety imposed by society. According to Calvet's formulation, argot "est une façon de se situer [...] une façon de revendiquer son appartenance à un groupe social, à un lieu ou à une classe d'âge" (1994: 115). In the 1930s, the effect sought by Maurice Chevalier was the same. He frequently used popular expressions for humorous effect and increased his notoriety with risqué and politically incorrect words.

What will become of Maurice Chevalier's argot? It seems, contrary to the suggestion of Colin (2000: 155), that classical argot is not dead. Indeed, it appears that one does not speak of argot anymore but of argots in the plural. Both a small death and a renaissance are going on simultaneously. Verlan for example is a social and geographical marker (commonly heard in 
the Parisian suburbs, but only very rare in the South of France). Certain frequent words however ("keuf", "meuf" etc.) are integrated into the language and used by various social groups. As the statistics have shown, Chevalier's argot is still in use despite strong competition: it is putting up a strong defence against verlan and forms from all sides, from English to Arabic, and Antillais and Romany languages (Gadet 2003: 2004) which young people pick up and which are disseminated by the media through television. Our survey indicates, fairly unsurprisingly, clear sex differences with male informants using proportionately more non-standard items and shows that $42 \%$ of the non-standard terms in the Chevalier's corpus are still used by the informants. The informants' judgements on the stylistic appropriacy of these items demonstrate they are becoming more uniform, although around $20 \%$ are considered to be archaic or outdated. The currency of non-standard lexis can ebb and flow in an unpredictable way, probably as a result of the media. For Bernet, "le lexique évolue de manière imprévisible à long terme et rien ne permet de dégager avec certitude des tendances qui pourraient préfigurer l'avenir" (Bernet 2000: 194). Recently, the singer Patrick Bruel revitalised the songs of 1930s with his album "Entre-deux" (2003) and it would not take much for the 1930s vocabulary to come back into fashion. 
Michaël Abecassis: French of the present and the past: the representation of the Parisian vernacular in Maurice Chevalier's songs

\section{Glossary}

The following glossary gives a representative sample of non-standard items in the Chevalier corpus with their translation in English and their acceptance in Le Petit Larousse (2004).

\begin{tabular}{|c|c|c|c|}
\hline Vocabulary & Songs in which it is found & $\begin{array}{c}\text { Label in Le } \\
\text { Petit } \\
\text { Larousse } \\
\text { (2004) }\end{array}$ & Meaning \\
\hline être un as & Oh Maurice!, Mimile & Fam. & To be ace \\
\hline un aminche & App'lez ça comme vous voulez. & Abs. & A mate \\
\hline de l'aubère & App'lez ça comme vous voulez & Abs. & Lolly \\
\hline avaler & Ça s'est passé un dimanche & Fam. & To swallow, to take \\
\hline badour & App'lez ça comme vous voulez & Abs. & Attractive \\
\hline une balade & Y'a d'la joie & Fam. & A stroll \\
\hline une baraque & Ça s'est passé un dimanche & Fam. & A dump \\
\hline se barrer & App'lez ça comme vous voulez. & Fam. & To clear off \\
\hline un bécot & Ça s'est passé un dimanche & Fam. & A peck \\
\hline becqueter & App'lez ça comme vous voulez. & Abs. & To nosh \\
\hline avoir le béguin & Quai de Bercy, Sur un air américain & Fam., vieilli & To have a thing on \\
\hline un bibi & Le chapeau de zozo & Fam., vieilli & A small woman's hat \\
\hline un bistrot & $\begin{array}{c}\text { Ma pomme, App'lez ça comme vous } \\
\text { voulez }\end{array}$ & Fam. & A local \\
\hline un bizness & Prosper, Mimile & Fam. & A job \\
\hline blaguer & Mimile & Fam. & To joke \\
\hline du blé & App'lez ça comme vous voulez. & Fam. & Dosh \\
\hline bosser & Mimile & Fam. & To slog away \\
\hline la bouille & Une brune, une blonde & Fam. & The mug \\
\hline la boule & Ah si vous connaissiez ma poule & Fam. & The head \\
\hline de la braise & App'lez ça comme vous voulez & Arg., vieilli & Dosh \\
\hline la bricole & Quai de Bercy & Fam. & Odd jobs \\
\hline briffer & App'lez ça comme vous voulez & Arg. & To pig oneself \\
\hline un caboulot & Ça s'est passé un dimanche & Vieilli, litt. & A dive \\
\hline calter & App'lez ça comme vous voulez & Fam. & To run away \\
\hline carguer la voile & App'lez ça comme vous voulez & $A b s$ & To clear off \\
\hline casé & Sur un air américain & Fam. & Fixed up \\
\hline un cave & App'lez ça comme vous voulez & Fam ou arg.. & A mug \\
\hline la cervelle & Mimi, Dans la vie faut pas s'en faire & Fam. & The brain \\
\hline chambouler & Paris sera toujours Paris & Fam. & To turn upside down \\
\hline chic & Mimile & Fam., vieilli & Stylish \\
\hline chiper & $\begin{array}{l}\text { Ah si vous connaissiez ma poule, } \\
\text { App'lez ça comme vous voulez }\end{array}$ & Fam. & To pinch \\
\hline du chiqué & Ma pomme & Fam. & Sham \\
\hline la chose & App'lez ça comme vous voulez & Abs. & Sex \\
\hline chouette & $\begin{array}{c}\text { App'lez ça comme vous voulez, Ma } \\
\text { régulière, Mimile }\end{array}$ & Fam. & Smashing \\
\hline une cocotte & Quai de Bercy & Fam. & A bird \\
\hline se cogner de trop & App'lez ça comme vous voulez & $A b s$. & To pig out \\
\hline un coq & Mimile & Abs. & A bit of a casanova \\
\hline la coqueluche & Mimile & Fam. & The darling of \\
\hline coller & Dans la vie faut pas s'en faire & Fam. & To foist sth to someone \\
\hline $\begin{array}{l}\text { comme un clou } \\
\text { (mince) }\end{array}$ & Oh Maurice ! & Abs. & As thin as a rake \\
\hline un copain & Ça s'est passé un dimanche & Fam. & A mate \\
\hline le coquillard & App'lez ça comme vous voulez & Fam., vieilli & The eye \\
\hline la croûte & App'lez ça comme vous voulez & Fam. & grub \\
\hline se crêper le chignon & Prosper & Fam. & To tear each other's hair out \\
\hline débiner & App'lez ça comme vous voulez & Fam. & To make off \\
\hline se démancher & Ma pomme & Fam. & To put oneself out to get sth \\
\hline
\end{tabular}




\begin{tabular}{|c|c|c|c|}
\hline $\begin{array}{c}\text { discuter le bout de } \\
\text { gras }\end{array}$ & App'lez ça comme vous voulez & Fam. & To have a good old natter \\
\hline dodo & Sur un air américain & Enf. & Sleep \\
\hline un doublard & ma régulière & Abs. & A pimp's second wife \\
\hline un drink & App'lez ça comme vous voulez & Fam. & A drink \\
\hline un dur & App'lez ça comme vous voulez & Fam. & A tough nut \\
\hline s'embêter & Y'a d'la joie & Fam. & To get bored \\
\hline s'empiffrer le cornet & S'empiffrer le cornet & Abs. & To pig out \\
\hline s'esquinter & $\begin{array}{c}\text { App'lez ça comme vous voulez, } \\
\text { Valentine }\end{array}$ & Abs. & To wear oneself out \\
\hline esquintant & Oh Maurice & Fam. & Exhausting \\
\hline extra dry & Quai de Bercy & Anglic. & Extra dry \\
\hline être à la page & Prosper, Marche de Ménilmontant & Fam. & To be up to date \\
\hline fauché & Quai de Bercy & Fam. & Broke \\
\hline en ficher un coup & Ça s'est passé un dimanche & Fam. & To clout someone \\
\hline se ficher & Quai de Bercy & Fam. & Not to give a darn about \\
\hline fichu & Oh Maurice ! & Fam. & To be done for \\
\hline se ficher à l'eau & Dans la vie faut pas s'en faire & Abs. & $\begin{array}{l}\text { To throw oneself into the } \\
\text { water }\end{array}$ \\
\hline flancher & Ça s'est passé un dimanche & Fam. & To fail \\
\hline un flic & Mimile & Fam. & A cop \\
\hline le figne & App'lez ça comme vous voulez & Abs. & The ass \\
\hline une fouille & App'lez ça comme vous voulez & arg. & A pocket \\
\hline du flouse & App'lez ça comme vous voulez & Arg. & Dosh \\
\hline (se) foutre & $\begin{array}{l}\text { App'lez ça comme vous voulez, Prosper, } \\
\text { Quand un vicomte }\end{array}$ & Très fam. & Not to give a damn \\
\hline bien foutu & Ah si vous connaissiez ma poule & Fam. & A nice bit of stuff \\
\hline le fric & $\begin{array}{l}\text { App'lez ça comme vous voulez, ma } \\
\text { régulière }\end{array}$ & Fam. & Dosh \\
\hline fringues & App'lez ça comme vous voulez & Fam. & Clothes \\
\hline un galurin & Le chapeau de zozo & Fam. & A lid \\
\hline un gamin & Valentine & Fam. & A kid \\
\hline une gapette & Mimile & Fam., vieilli & A cap \\
\hline un gars & $\begin{array}{l}\text { Marche de Ménilmontant, L'amour est } \\
\text { passé près de chez vous, Mimile }\end{array}$ & Fam. & A bloke \\
\hline un gavroche & Mimile & Vieilli & A street urchin \\
\hline un glass & App'lez ça comme vous voulez & Abs. & A drink \\
\hline un gnon & Prosper & Fam. & A blow \\
\hline un godet & App'lez ça comme vous voulez & Abs. & A drink \\
\hline une gonzesse & Prosper, App'lez ça comme vous voulez & Fam. & A hen \\
\hline une gosse & ma régulière & Fam. & A young girl \\
\hline gouaille & Ça s'est passé un dimanche & Fam. & Cocky humour \\
\hline gueuler & App'lez ça comme vous voulez & Fam. & To bawl \\
\hline hisser le grand foc & App'lez ça comme vous voulez & Abs. & To clear off \\
\hline une jaquette & Y'a d'la joie & Abs. & A jacket \\
\hline un jeunot & Marche de Ménilmontant & Fam. & A young lad \\
\hline Lap' & Ah si vous connaissiez ma poule & Abs. & La rue de la Paix in Paris \\
\hline mon loup & Valentine & Abs. & My darling \\
\hline en lousdoc & App'lez ça comme vous voulez & Abs. & On the quiet \\
\hline un macadam & Mimile, Prosper & Abs. & To walk the streets \\
\hline un machin & Quai de Bercy & Fam. & A thingummy \\
\hline un malabar & Prosper, App'lez ça comme vous voulez & Fam. & A muscle man \\
\hline un marle & App'lez ça comme vous voulez & Abs. & A pimp \\
\hline se marrer & Prosper & Fam. & To laugh \\
\hline un mastroquet & Mimile & Fam., vieilli & A publican \\
\hline un mec & App'lez ça comme vous voulez & Fam. & A guy \\
\hline Ménilmuche & $\begin{array}{l}\text { Ah si vous connaissiez ma poule, } \\
\text { Marche de Ménilmontant, Mimile }\end{array}$ & Abs. & $\begin{array}{c}\text { Ménilmontant } \\
\text { (district of Paris) }\end{array}$ \\
\hline $\begin{array}{c}\text { s'en mettre plein les } \\
\text { trous de nez }\end{array}$ & App'lez ça comme vous voulez & Abs. & To pig out \\
\hline mézigue & App'lez ça comme vous voulez & Arg. & $\mathrm{Me}$ \\
\hline une miss & Le chapeau de zozo & Fam. & A young girl \\
\hline
\end{tabular}



vernacular in Maurice Chevalier's songs

\begin{tabular}{|c|c|c|c|}
\hline une môme & $\begin{array}{c}\text { Mimi, Ah si vous connaissiez ma poule, } \\
\text { Quai de Bercy }\end{array}$ & Fam. & A young girl \\
\hline monter au cerveau & Quai de Bercy & Abs. & To go to somebody's brain \\
\hline un morlingue & App'lez ça comme vous voulez & Abs. & A purse or wallet \\
\hline $\begin{array}{l}\text { de la mousse (se } \\
\text { faire) }\end{array}$ & Ma pomme & Abs. & To worry oneself sick \\
\hline un moutard & Ça s'est passé un dimanche & Fam. & A brat \\
\hline une musaraigne & App'lez ça comme vous voulez & Abs. & A bird \\
\hline une nénesse & App'lez ça comme vous voulez & Abs. & A bird \\
\hline nib & Ah si vous connaissiez ma poule & Arg. & Nothing \\
\hline un pain & Ma régulère & Fam. & A blow \\
\hline un pajot & App'lez ça comme vous voulez & Arg. & A bed \\
\hline un palace & Ma pomme & Angl. & A first-rate hotel \\
\hline Pantruche & Ah si vous connaissiez ma poule & Abs. & Pantin (district of Paris) \\
\hline un papeau & Le chapeau de zozo & Abs. & A lid \\
\hline un parigot & App'lez ça comme vous voulez, Mimile & Fam. & A Parisian \\
\hline un patelin & Une brune, une blonde & Fam. & A dump \\
\hline peinard & Ma pomme & Fam. & Jammy \\
\hline un peton & Valentine & Fam. & A tiny foot \\
\hline le pèze & $\begin{array}{c}\text { Ma pomme, App'lez ça comme vous } \\
\text { voulez }\end{array}$ & Arg. & Dosh \\
\hline piailler & ma régulière & Fam. & To screech \\
\hline piauler & App'lez ça comme vous voulez & Fam. & To whine \\
\hline des picaillons & App'lez ça comme vous voulez & Fam. & Dosh \\
\hline le pinard & Quai de Bercy & Fam. & plonk \\
\hline en pincer & Ma pomme & Fam. & To have a crush on \\
\hline un piton & Valentine & Abs. & A nose \\
\hline plein les poches & App'lez ça comme vous voulez & Fam. & Loaded with money \\
\hline plier boutique & Y'a d'la joie & Abs. & To clear off \\
\hline un plume & App'lez ça comme vous voulez & Abs. & A bed \\
\hline une pomme & Ma pomme & Fam. & $\mathrm{Me}$ \\
\hline pompé & App'lez ça comme vous voulez & Fam. & nackered \\
\hline un portrait & Ma pomme & Fam. & A face \\
\hline un pot & App'lez ça comme vous voulez & Fam. & A drink \\
\hline un poteau & $\begin{array}{c}\text { Ma pomme, App'lez ça comme vous } \\
\text { voulez }\end{array}$ & Fam. & A mate \\
\hline une poularde & Mimi & Abs. & A bird \\
\hline une poule & $\begin{array}{l}\text { Ah si vous connaissiez ma poule, } \\
\text { App'lez ça comme vous voulez, ma } \\
\text { régulière, Mimile }\end{array}$ & Fam. & A bird \\
\hline une profonde & App'lez ça comme vous voulez & Abs. & Pocket \\
\hline le prose & App'lez ça comme vous voulez & Abs. & The ass \\
\hline un prout prout & Prosper & Abs. & A fart \\
\hline un pucier & App'lez ça comme vous voulez & Arg. & A fleabag \\
\hline un radis & $\begin{array}{l}\text { Quai de Bercy, Dans la vie faut pas s'en } \\
\text { faire }\end{array}$ & Fam. & A penny \\
\hline ramener sa fraise & App'lez ça comme vous voulez & Fam. & To show up \\
\hline une régulière & $\begin{array}{l}\text { App'lez ça comme vous voulez, ma } \\
\text { régulière }\end{array}$ & Abs. & A missus \\
\hline remettre ça & App'lez ça comme vous voulez & Fam. & To have another go \\
\hline renifler (du vin) & Quai de Bercy & Abs. & To drink \\
\hline rien dans les poches & Quai de Bercy & Fam. & Broke \\
\hline roucouler & Ah si vous connaissiez ma poule & Fam. & To coo \\
\hline un roussin & Prosper & Arg., vx & A cop \\
\hline un roudoudou & Mimi & Abs. & A sweetheart \\
\hline un salop & App'lez ça comme vous voulez & Vulg, injur. & A bastard \\
\hline $\begin{array}{l}\text { sauter jusqu'au } \\
\text { plafond }\end{array}$ & Ah si vous connaissiez ma poule & Abs. & To jump for joy \\
\hline un schnok & App'lez ça comme vous voulez & Fam. & An old geeser \\
\hline un snobard & Ma pomme & Abs. & A snob \\
\hline un sou & Mimi & Fam. & A penny \\
\hline
\end{tabular}




\begin{tabular}{|c|c|c|c|}
\hline des sous sous & App'lez ça comme vous voulez & Abs. & Dosh \\
\hline une souris & App'lez ça comme vous voulez & Abs. & A bird \\
\hline sucer des clous & App'lez ça comme vous voulez & Abs. & To eat nothing \\
\hline sympa & Mimile & Fam. & Nice \\
\hline se taper le chou & App'lez ça comme vous voulez & Abs. & Not to overtax oneself \\
\hline le tapin & ma régulière & Très fam. & To walk the streets \\
\hline une tatane & App'lez ça comme vous voulez & Fam. & A shoe \\
\hline un titi & Ça sent si bon la France, Mimile & Fam. & A Parisian street urchin \\
\hline le trac & L'amour est passé près de chez vous & Fam. & To have butterflies in one's \\
& Quai de Bercy, ma régulière & Arg., vx & The road \\
\hline le trimard & Ma régulière & Abs. & A pimp's third wife \\
\hline un triplard & App'lez ça comme vous voulez & Fam. & To run away \\
\hline trisser & Sur un air américain & Fam., vx & An errand girl \\
\hline un trottin & Quai de Bercy & Fam.. & Grind \\
\hline le turbin & App'lez ça comme vous voulez & Abs. & The arse \\
\hline le vase & Ah si vous connaissiez ma poule & Fam. & Jammy \\
\hline veinard & App'lez ça comme vous voulez & Abs. & A jammy chap \\
\hline un verjot & Valentine & Abs. & To take a dekko \\
\hline viser & Oh Maurice! & Fam. & To wish to get someone \\
\hline vouloir la peau de & App'lez ça comme vous voulez & Abs. & A weirdo \\
\hline un zigomar & Paris sera toujours Paris & Fam. & A fool \\
\hline un zouave & Le chapeau de zozo & Fam. & A mug \\
\hline un zozo & & & \\
\hline & & & \\
\hline
\end{tabular}

Table 9: Glossary of non-standard items in Chevalier's corpus

\section{References}

Abecassis Michaël (2000): "A diachronic analysis of non-standard vocabulary in the dialogues of 1930s French films". Te Reo: Journal of the Linguistic Society of New Zealand 43: 21-37.

Antoine, Gérald/Cerquiglini Bernard (2000): Histoire de la langue française 1945-2000. Paris.

Antoine, Gérald/Martin, Robert (eds.) (1995) Histoire de la langue française (1914-1945). Paris: 191-206.

Armstrong, Nigel/Hogg, Clare (2001): "The Pollyanna principle in French : a study of variable lexis". Journal of Pragmatics 33, 11: 1757-1785.

Armstrong, Nigel/Unsworth, Sharon (1999): "Sociolinguistic Variation in Southern French Schwa". Linguistics 37,1: 127-155.

Bauer, Laurie (1994): Watching English Language: An Introduction to the Study of Linguistic Change in Standard Englishes in the Twentieth Century. New York.

Baylon, Christian (1991): Sociolinguistique: Société, langue et discours. Paris.

Bernet, Charles (1995): "Le français familier et populaire à la radio et au cinéma". In: Antoine, Gérald/Martin, Robert (eds.) (1995): Histoire de la langue française (1914-1945). Paris: 191-206.

Bernet, Charles (2000): "Usage et marges du lexique français". In: Antoine Gérald/Cerquiglini Bernard (eds.): Histoire de la langue française (1945-2000). Paris: 152-172.

Calvet, Louis-Jean (1994): L'Argot. Collection Que Sais-Je? 700. Paris.

Carton, Fernand (1995): "La prononciation du français". In Antoine, Gérald/Martin, Robert (eds.): Histoire de la langue française (1914-1945). Paris: 27-52. 
Chambers, Jack K. (2003): Sociolinguistic theory: Linguistic Variation and its Social Significance. Oxford,/Cambridge.

Chambers, Jack K. (1998): "Myth 15: TV makes people sound the same" In: Bauer L./ Trudgill P.(eds): Language Myths. Harmondsworth. Penguin books: 123-31.

Colin, Jean-Paul (2000): "Nouvelles pratiques langagières: les argots". In: Antoine, Gérald/Cerquiglini, Bernard (eds): Histoire de la langue française (1945-2000). Paris: 152-172.

Françoise, Densie (1985): " Les argots ". In: Antoine Gérald/Martin, Robert (ed.): Histoire de la langue française (1880-1914). Paris: 295-327.

Françoise, Gadet (1989): Le Français ordinaire. Paris.

Françoise, Gadet (1992): Le Français populaire. Collection Que Sais-Je? 1172. Paris.

Françoise, Gadet (2003): "'Français populaire' : un classificateur déclassant ?". Marges linguistiques 6:103-115.

Françoise, Gadet/Conein, Bernard (1998): " 'Le 'français populaire' de jeunes de la banlieue parisienne entre permanence et innovation". In: Androutsopoulos, Jannis K./Scholz, Arno (eds.): Jugendsprache - langue des jeunes - Youth Language. Frankfurt am Main/New York: 105-123.

Goose, André (2000): "Evolution de la Syntaxe". In: Antoine, Gérald/Cerquiglini, Bernard (eds): Histoire de la langue française (1945-2000). Paris: 105-145.

Goudailler, Jean-Pierre (2000): "Comment le céfran des cités a fait souffler un véritable air de jeunesse sur le français de papa". Le Nouvel Observateur Hors série 41: available at http://www.nouvelobs.com/hs-lesados/instruire/art8.html.

Guiraud, Pierre (1965): Le Français populaire. Collection Que Sais-Je? 1172. Paris.

Holmes, Janet (1997): "Setting new standards: sound change and gender in New Zealand English" English World-Wide 18,1: 107-142.

Labov, William (1984): "The transmission of linguistic traits across and within communities". Paper presented at the Symposium on Language Transmission and Change, Center for Advanced Study in the Behavioral Sciences, Stanford University, California.

Lieberson, Stanley (2000): A Matter of Taste: How Names, Fashions and Cultures. Yale.

Lodge, R. Anthony/Armstrong, Nigel/ Ellis, Yvette M.L./Shelton, Jane F. (1997): Exploring the French Language. London.

Milroy, Lesley (1987): Language and Social Networks. Oxford.

Milroy, Lesley/Gordon, Matthew (2003): Sociolinguistics: Methods and Interpretation. Blackwell.

Müller, Bodo (1985): Le Français d'aujourd'hui. Paris.

Petitpas, Thierry (2003): "De Paname à Ripa: histoire d'une rupture" Marges linguistiques 6: 145-155.

Posner, Rebecca (1997): Linguistic Change in French Language. Oxford: Clarendon Press.

Szabó, Dávid (1998): "Methodological Problems of the Sociolinguistic Study of Youth Slang". In: Androutsopoulos, Jannis K./Scholz, Arno (eds.): Jugendsprache - langue des jeunes - Youth Language. Frankfurt am Main/New York: 48-57.

Tranel, Bernard (1987): The Sounds of French. Cambridge. 
Walter, Henriette (1991): "Où commencent les innovations lexicales". Langue française: 5364.

Wardhaugh, Ronald (1986/1992): An Introduction to Sociolinguistics. Oxford. 